\title{
Destruction of a fluvial reservoir by hydrothermal activity (Cameros Basin, Spain)
}

\author{
M. Ochoa ${ }^{\text {a,* }}$, J. Arribas ${ }^{\text {a }}$, R. Mas ${ }^{\text {b }}$, R.H. Goldstein ${ }^{\text {c }}$ \\ a Departamento de Petrologia y Geoquimica, Universidad Complutense de Madrid, Facultad de Ciencias Geológicas, \\ C/ José Antoni Novais 2, 2844, Madrid, Spain \\ b Departamento de Estratigrafia, Universidad Complutense de Madrid, Facultad de Ciencias Geológicas, \\ Cl José Antoni Novais 2, 2814, Madrid, Spain \\ ${ }^{c}$ Department of Geology, University of Kansus 1475 Jayhwk Boulevard, 120 Lindley Hall, Lawrence, Kansas 66045-7613, USA
}

\begin{abstract}
This study provides an example of a high-quality fluvial hydrocarbon reservoir that was completely destroyed by hydrothermal processes. The reservoir unit was deposited in the Cameros Basin, located in the NW sector of the lberian Chain (Spain). The basin was filled with clastic fluvial deposit (sandstones and conglomerates) between Late Berriasian and Early Aptian times. Provenance of sands was mainly from coarse crystalline rocks. A humid ropical climate produced intense weathering of K-feldspar during ransport from source to basin. Thus, a mineralogically mature rigid framework with high porosity existed at the time of deposition, which would have constituted a high-quality hydrocarbon reservoir. At present however, the porosity of the reservoir is negligible. Porosity was reduced by a sequence of diagenetic processes: (1) mechanical compaction (i.e. crushing of metamorphic lithic grains) and chemical compaction, (2) kaolinite and siderite cementation, and (3) early quartz cementation. Hydrocarbon emplacement probably occurred between phases (2) and (3). A low-rade metamorphic (hydrotbermal) event, reaching greenschist facies, took place during the Late Cenomanian. It dramatically reduced the remaining porosity of the reservoir and destroyed the hydrocarbon charge. Hydrothermal processes which affected the sandstones include (1) re-compaction; (2) late quartz cementation and silicification of remaining feldspars; (3) carbonate cementation; (4) chloritization of feldspars, metamorphic lithic fragments and intrabasinal argillaceous rains; and (5) growth of pyrite and chloritoid crystals on argillaceous material of in trabasinal, extrabasinal or even diagenetic origin. Hydrocarbons that migrated to the margins of the basin escaped these hydrothermal modifications and were preserved. The result of this study may be used to predict the diagenetic and hydrothermal evolution of other potential reservoirs in similar tectonic settings.
\end{abstract}

Keywerds: Sandstone diagenesis; Hydrothennal activity; Metamorphism; Porosity reduction; Cameros Basin; Spain

\section{Introduction}

Amøng the Mesøzic basins of the Iberian Chain (Spain), the Cameres Basin preserves the most complete sedimentary record of the time interval from the
Tithenian to the Early Albian (Fig. 1). During this period, the anomalously high subsidence and sedimentation rates within the basin preduced a sedimentary record that reached up to $5 \mathrm{~km}$ in vertical thickness (representing up to $9 \mathrm{~km}$ of stratigraphic record in the direction of the northward migration of the successive depesitional sequences which filled the basin). Tw• sectors with different features can be distinguished: the 


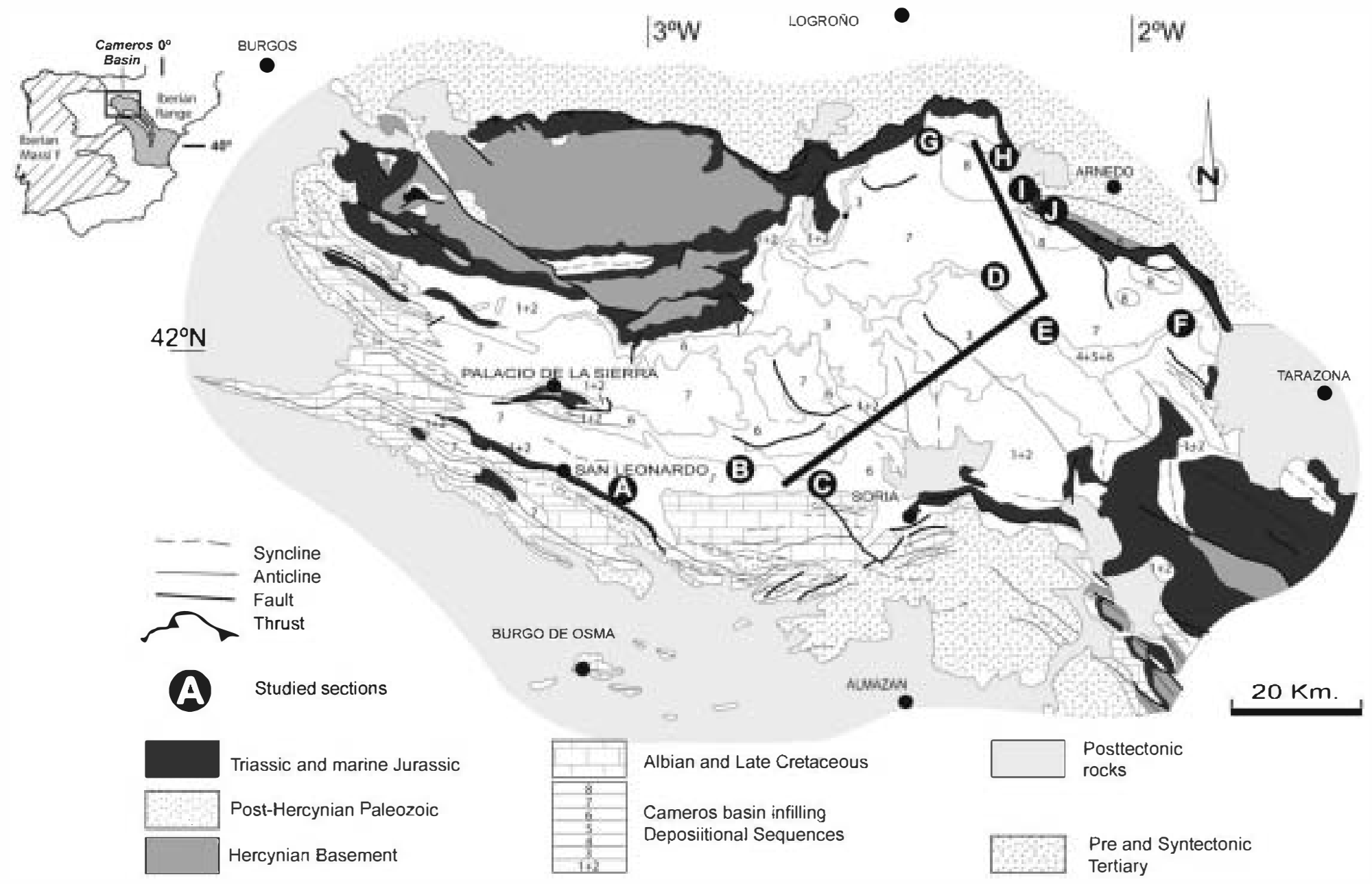

Fig. 1. Simplified geologic map showing study areaand location of the transect through the outcrops. The stratigraphic sections are located in Muriel (A), Cidones-Abejar (B), Golmayo (C), Yanguas (D), San Pedro Manrique (E), Valdemadera (F), Trevijano (G), Jubera (H), Amedillo (I) and Préjano (J). 
northeastern sector, characterized by the most rapid rates -f subsidence and affected by low-grade (hydrothermal) metamorphism; and the southwestern sector, characterized by the presence of secondary depecenters and unaffected by metamorphism.

The føcus $\bullet$ this study is the nørthern and central part $\bullet$

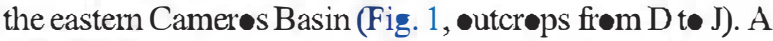
SW-NE trending ge $\bullet$ gical cross-section from this area is shown in Fig. 2. In this area, Mas et al. (2003) described eight depesitional sequences (DS) ranging in age from Tithonian to Early Albian (Fig. 3). This study is focused on the maximum syn-rift filling stage (DS-4 t• DS-7), from Late Berriasian to Early Aptian (Urbión Grøup), in which a succession of up to $2.2 \mathrm{~km}$ of clastic sediments was formed.

Although there are many publications dealing with stratigraphy, sediment•løgy and mineraløgy •fthe Urbión Group (e.g. Salinas and Mas, 1989; Casquet et al., 1992; Mas et al., 1993; Aløns•-Azcárate et al., 1995; Mantilla et al., 1998; Aløns-Azcárate et al., 1999a,b; Barrenechea et al., 2001; Mata et a1., 2001; Mantilla et al., 2002; Mas et al., 2003), little attention has been paid to reservoir characterisation and evaluation of these clastic sediments
(Arribas et al., 2003). The petrøleum systems of the basin are discusse by Mas et a1. (2002). The absence of hydrocarbons in the basin fill prompted the present analysis -f the metamorphic (hydrothermal) processes that caused their destruction.

This paper documents the destructive effects of burial diagenesis and løw-grade hydrøthermal metamorphism $\bullet$ n reservoir quality, and prøvides insights int the evolution - fhydrecarbon reserv irs in ther basins affected by these processes. Hydrothermal alteration of clastic reservoirs has been frequently documented (i.e., Høffman and Hower, 1979; Larese, 1997). Cømmøn related processes include mineral cementation and recrystallization, generated by acid hot water flows, which promotes poresity/ permeability reduction (i.e., Oelkers et al., 1996; De Ros et al., 2000). Lew-grade hydrothermal metamorphism may produce a complete cclusion of fluid pathways in the reservoir (Dutkiewicz et al., 1995; Buick et al., 1998). In many basins hydrothermal metamorphism develops løcally, and preservation $\bullet$ f econ॰mically expløitable reserv $\bullet$ irs may $\bullet c c u r$ in areas of the basin unaffected by metamorphism (Spötl et al., 1994; Pittman and Spë1t, 1996; Spötl et al., 2000). Thus, understanding the processes that

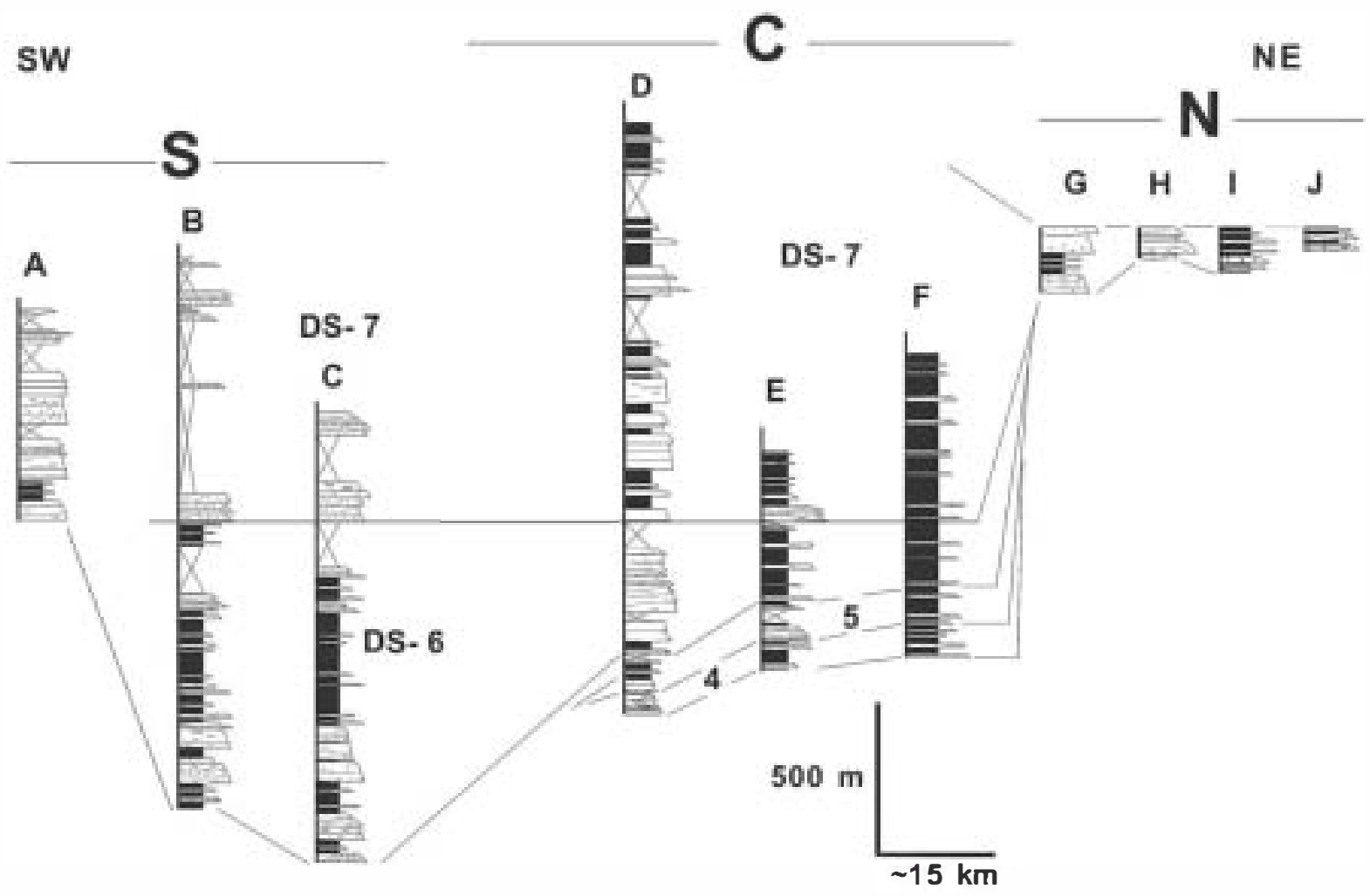

Fig. 2. Sratigraphic ansect of Urbión Group through the southern area (S), cen area (C) and northern area (N) of the basin. See Fig. 1 for location of sections. 


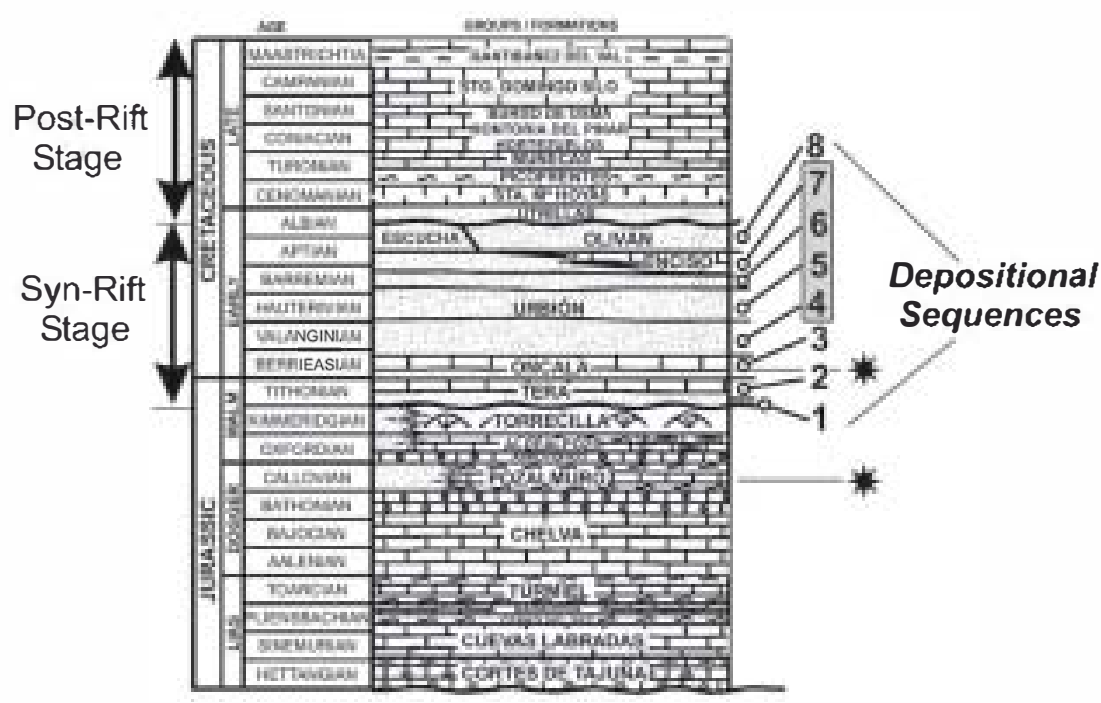

\section{* Source Rocks Urbión Group}

Fig. 3. Rift and post-rift stages in the evolution of the Iberian Basin (Modified from Salas et al., 2001) and idealised stratigraphic section showing the latest Paleozoic and Mesozoic sratigraphic record in the Cameros area.

affected "palae -reserv $\bullet$ ir" quality is an imp•rtant •bjective in predictive diagenetic reservoir modelling.

\section{Geological setting}

The Cameres Basin is an intracratenic basin, representing a folded segment of the Alpine Chain that developed as a consequence of the contractional inversiøn $\bullet$ the Mesøzic Iberian rift basin. The develøpment -f this basin took place in tw॰ phases: the first phase lasted from Early Permian to the Late Triassic and the secønd from Tithønian to Early Albian. These twe rifting phases were followed by pest-rift thermal subsidence, during which mainly shallow marine carbnates were dep॰sited (Guimerà et al., 1995; Salas et al., 2001) (Figs. 1-3).

During the second stage of rifting, a thick succession ( $<5 \mathrm{~km}$ total thickness) of alluvial to lacustrine, dep sitional sequences was accumulated in the depøcentre of the Cameres Basin (Fig. 3). According to Mas et al. (2003), the basin fill constitutes a large megasequence bounded by twe main unconformities (Fig. 3). The megasequence can be subdivided int e eight depesitional sequences (DS-1 to 8); this study focused on the interval between DS-4 and DS-7, which constitutes the Urbion Group.

The thickness of the Urbion Group varies dramatically from $100 \mathrm{~m}$ in the marginal areas of the basin to $2200 \mathrm{~m}$ in the depocentres (Fig. 2). It comprises sand- stones and conglomerates interbedded with shales, which were deposited in settings ranging from braided systems (Mas et al., 2003) in the southwestern area of the basin (A to $\mathrm{C}$ in Fig. 1) to meandering fluvial and lacustrine systems (Mas et al., 2003) in the central and northeastern areas (D to F in Fig. 1); and alluvial-fan facies (Mas et al., 2003) in the northern part of the basin (G to $\mathrm{J}$ in Fig. 1).

\section{Basin evolution, potential source rocks and metamorphism}

Mas et al. (2003) summarized the genesis and ev-lution of the Cameros Basin (Fig. 4). Extensive carbønate platforms develøped during Jurassic times, i.e., before the Tithønian to Early Albian rifting phase (1, in Fig. 4). The Cameros Trough began to form as an extensional ramp basin from Tithønian to Berriasian time. Depesitional Sequences 1 to 3 were deposited in this time interval (2, in Fig. 4). The maximum thickness -f strata is reached in the DS-4 to DS- 8 dep $\bullet$ sits of the central zone, corresponding to the time interval of maximum extension from Berriasian to Early Albian. This initiated organic matter maturation and hydrecarben migration towards permeable units in the basin ( $3 \mathrm{a}$ and 3b, in Fig. 4). Marine envirøments re-eccupied the Cameres area during the Late Cretaceøs, constituting the Post-Rift Stage 2. During Cenømanian times, hydrethermal metamerphism affected a significant v•lume $\bullet$ 


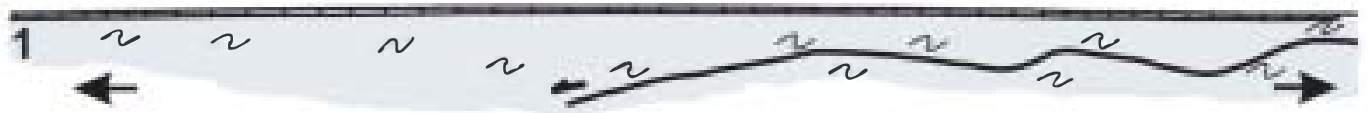

Starting of the rifting.

S Deposition of the Tithonian and Berriasian

$\mathbf{N}$

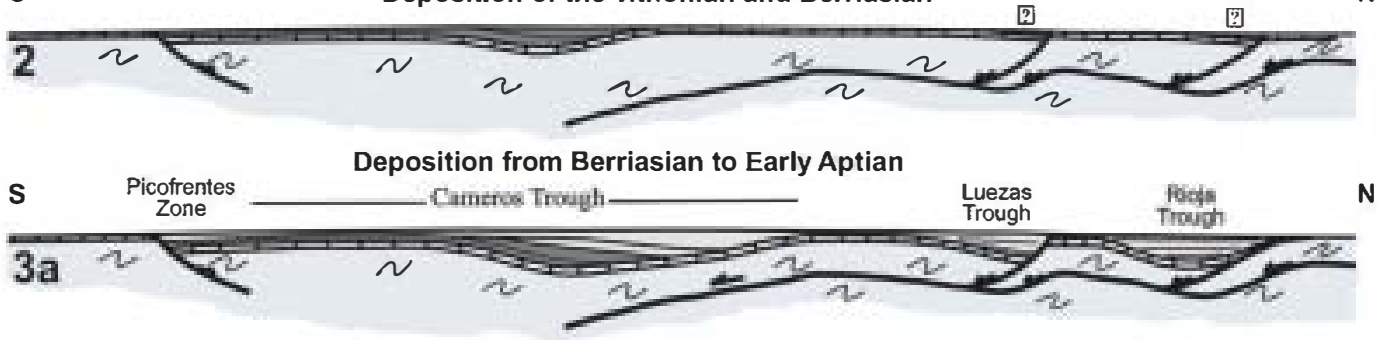

S Deposition of the Late Aptian-Early Albian. End of the rifting. Maturation and migration of hydrocarbons

$\mathbf{N}$

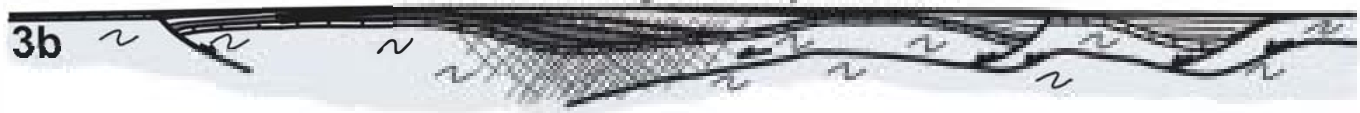

Seposition of the Late Crataceous post-rift.

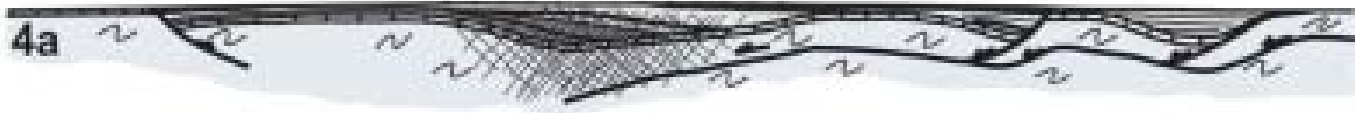

Metamorphism of the basin (Late Cenomanian)

$\mathbf{N}$
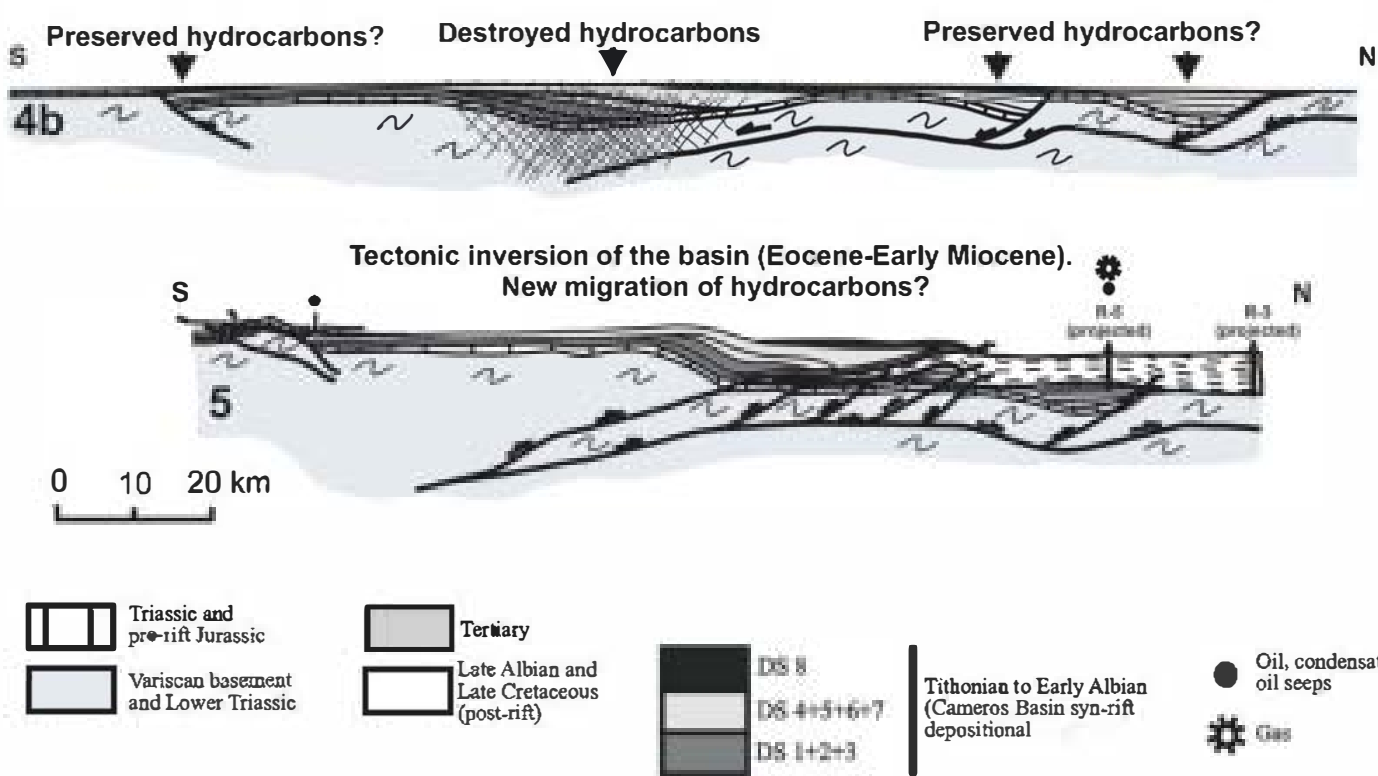

Tithonian to Early Albian (Cameros Basin syn-rift depositional

$N$ 
half-graben sub-basins (Riøja Trøugh to the North and Bigornia Trøugh to the South). The Cameros Trough is considered the central part of the Cameros Basin in which hydrothermal activity took place (Mas et al., 2003), and where early generation and migration of $\bullet$ il

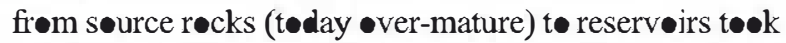
place. Pøtential søurce røcks $\bullet$ the Camerøs Trøugh are Calløvian organic marls and black shales (type II, Tiss $\bullet$ and Welte, 1978), Early Cretaceous lacustrine organic marls, (type II/I, Tissot and Welte, 1978), and syn-rift Early Cretaceus lignites and organic-rich shales (type III, Tisset and Welte, 1978) (Mas et al., 2003). Amøng the most impertant reserveirs were syn-rift, Early Cretace us charmelized fluvial sandstones (DS 4 to 7) (Mas et al., 2003). The recks that represented the seals at that time were the interbedded mudstones. The timing of hydrocarbon generation can be considered as early and produced in twe events: (1) Albian, during which organic matter matured by burial and (2) Late Cretaceous, during which maturation of organic matter was induced by abnormal heat flow caused by the first hydrothermal event (Mas et al., 2003). The early emplacement of hydrecarbons is supperted by petregraphy as they predate quartz evergrewths.

The metamorphism of the basin is considered as hydrothermal and allochemical (Casquet et al., 1992; Barrenechea et al., 1995; Aløns-Azcárate et al., 1995, 2001; Mantilla et al., 2002). Tw• thermal events can be recognized (e.g. Mantilla et al., 2002). The first one is the most relevant here and took place after complete filling of the basin. It has been dated at the post-rift age of 106 to $86 \mathrm{MaBP}$ (frøm Late Albian to Cøniacian). Metamørphic conditions ranged from low-grade to very low-grade, with a maximum temperature of $340-370^{\circ} \mathrm{C}$ and a maximum pressure of $1 \mathrm{kbar}$ (aprøx. $3900 \mathrm{~m}$ ). This hydrothermal event coincides with other regional geotectonic events such as the •pening of the Gulf $\bullet$ Biscay (Olivet et al., 1984), and is coincident with the age of the alkaline magmatism in the Pyrenees (Montigny et al., 1986). Anøther hydr thermal phase has been recorded at $40 \mathrm{Ma}$ (Paleogene). This phase was related to the beginning of basin inversion during the Alpine contraction.

\section{Methods}

Sandstone sampling was canied out in several stratigraphic sections (Figs. 1, 2). In the southern part of the basin, these sections are located at Muriel (A), Cidones-

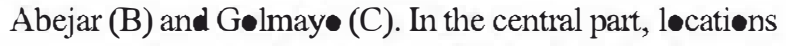
-f the sections are Yanguas (D), San Pedr• Manrique (E) and Valdemadera (F). In the north, locations of these sections are Trevijan• (G), Jubera (H), Arnedill• (I) and
Préjan• (J). Abøut 150 samples of sandstone were analysed to determine clastic and authigenic products. Analytical methøds included conventional petrography, fluid inclusion microthermømetry, cathødoluminescence, and analyses with electrøn micrøprøbe and scarming electrøn microscope (SEM).

Før petrographic analysis, standard doubled-pølished thin sections were etched and stained using HF and sødium cobaltinitrite for potassium feldspar identification, and alizarin red and pøtassium ferrecyanide t॰ better distinguish carbønate compønents (Chayes, 1952; Lindhølm and Finkelman, 1972, respectively). Føur hundred pøints were counted per sample for quantitative petrographic analyses. The "Gazzi-Dickinsøn" methød (Ingersøll et al., 1984) and petrographic groups defined by Zuffa (1980) were used to classify pøints. Post-depesitional changes to the original framework were alsø considered and evaluated. These analyses permit a reconstruction $\bullet$ the original framework compesition required for provenance deductions and diagenetic inferences.

Electron microprobe analysis was used to characterise carbonates cements, feldspars, clay minerals and

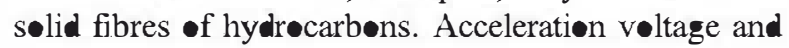
sample current intensity were set at $15 \mathrm{Kv}$ and $20 \mathrm{nA}$. Standards used were TAP, LD2, PETJ, PETJH, LF and LFH. Many images were taken under the microprobe in backscattered light in order to rec^gnize different brightness levels.

Døuble-pølished thin rock slices detached from their glass mount were prepared frøm most samples for fluid inclusion microthermometric analysis. The thickness $\bullet$ the slices was between 30 and $50 \mu \mathrm{m}$. In all cases, cold preparation techniques were use to aveid re-equilibra-

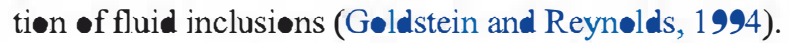
The measurements were carried out on a petrographic microscope equipped with a Linkam THMSG 600 heating and coøling stage which enables temperatures $\bullet$ phase transitions in the range of $-180^{\circ}$ to $300^{\circ} \mathrm{C}$. This heating stage is mounted on an Olympus BX60 polarizing micrescepe.

Small fragments of double-pølished reck slices were als• imaged under CL using an Oxford Instrument phøt॰multifilter-based CL detector installed on a JEOL T330 SEM. Cathødoluminescence phøtography was performed after homogenisation temperatures had been determined in order to av $\bullet$ id any negative effects on data acquisition.

SEM-CL textures were used to verify that the studied fluid inclusions were located in quartz cement and not in quartz clasts, to evaluate the possibility of finding søme zoning inside the quartz $\bullet$ vergrowth itself, and alsø to determine the timing of quartz cementation relative to 
-ther diagenetic prøcesses. The latter contributed to establishing the diagenetic sequence on the basis of textural relationships.

\section{Results}

\subsection{Petrofacies}

Following the criteria of Dickinsen (1985), it is possible to note a trend in framework compesition from South to North (Fig. 5). In proximal zones (søuthern area), the sandstone composition is quartzofeldspathic (mean $\mathbf{Q}_{81} \mathrm{~F}_{18} \mathrm{Lt}_{1}$; Fig. 6A) and $\mathrm{K}$-feldspar prevails over plagioclase. Sandstones from the søuthern part correspond to subarkeses instead of ideal arkeses due to chemical weathering in a tropical climate, which promoted a rapid decay of feldspars (Ochøa et al., 2004). These røcks evelve to more mature quartzese sandstones in depocentres (mean $\mathbf{Q}_{6} \mathrm{~F}_{3} \mathrm{Lt}_{1} ; \mathrm{Fig}$. 6B) suggesting significant mineralegical and textural maturation during transport over a distance of $>50 \mathrm{~km}$. This systematic spatial variation can alse be attributed to intense weathering in a humid climate (Rat, 1982). In addition, løcal sources of Triassic and Jurassic sedimentary rocks (carbønate and clastics) produced quartzelithic sandstone petrofacies (mean Q $_{3} \mathrm{~F}_{1} \mathrm{Lt}_{6}$ ) (Fig. 6C), in alluvialfan envirøments in the northeastern part $\bullet$ the basin. In spite of the different petrofacies, all sandstones are considered to have an original quartz-rich rigid framework. Their mean grain-sizes range from fine to cœarse. They are moderately to well sorted, which suggests that the riginal poresity was between $34 \%$ and $40 \%$ (Beard

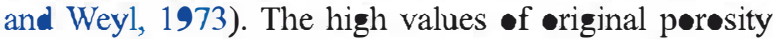
and the relatively low clay content characterize these depesits as very geod reserv॰ir røcks.

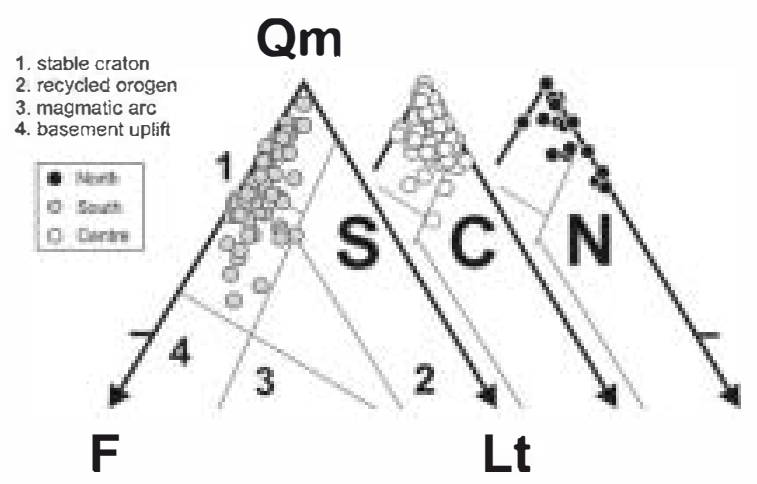

Fig. 5. Temary plots showing sandstone petrofacies in the Urbión Group (according to Dickinson, 1985) in the southem area (S), central area (C) and northem area (N) of the basin. Qm: Monocrystalline quartz; F: K-feldspar; Lt: total lithic population.

\subsection{Diagenetic and hydrothermal processes and products}

Urbión Group sandstones experienced intense diagenesis. The most relevant processes are indicated in Fig. 8.

\subsubsection{Compaction}

Compaction has been evaluated following the criteria -f Houseknecht (1987) and Lundegard (1992) for estimation of the intergranular volume of the original sediment and its reduction during diagenesis. Poresity loss by compaction (COPL, Lundegard, 1992) in the analyzed sandstones ranges from $11.9 \%$ to $37.29 \%$ for sandstones in the north; from $23.6 \%$ to $39.6 \%$ in the central area; and from $15.4 \%$ to $39 \%$ in the south (Table 1). Note that these values include both mechanical and chemical compaction. According to Lundegard (1992), the ICOMPACT (Cømpactional Index $=\mathrm{COPL} /(\mathrm{COPL}+\mathrm{CEPL}))$ in the Urbión Group varies between 0.6 and 0.9, indicating that compaction can be considere the main precess respensible for porøsity loss (Figs. 7A and 9). Likewise, different diagenetic pathways of sandstones from the north, centre and south indicate that compaction has most strøngly affected the central part of the basin, which has experienced the most subsidence.

\subsubsection{Cements and replacements}

Several diagenetic precipitates eccluded the intergranular pore space. Søme of these replace framework cœmp^nents or $\bullet$ ther cements.

\subsubsection{Clay Minerals. Ka Kinite $\bullet$ ccurs as pore-filling} cement in all areas, occupying intergranular pore space and $\bullet$ ccasionally as replacement of K-feldspar, generat-

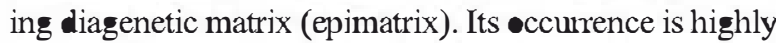
variable (mean $\mathbf{0 . 7 \%}, 1.6 \%, 8.9 \%$ in the northern, central and southern areas respectively).

It is possible to distinguish tw generations of pøre filling, an earlier generation included in the ediagenesis and a later generation that fills secondary pores. The first pore filling appears to be enclosed by other cements and deformed by mechanical compaction, which suggest an

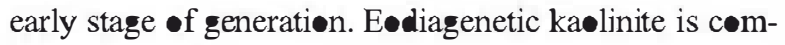
mon in warm and wet continental environments (i.e. Worden and Morad, 2003). The last phase shows vadose features and is included in the telodiagenetic stage. It has $\bullet$ nly been recognized in samples from the søuthern area $\bullet$ the basin. Telødiagenetic ka linite must be asseciated with an influx of løw-pH mete ric waters during uplift (Lansøn et al., 2002; Ketzer et al., 2003; Worden and Morad, 2003).

Illite appears as pore lining arøund detrital grains and as replacements of $\mathrm{K}$-feldspar (epimatrix, Fig. 6E). The 

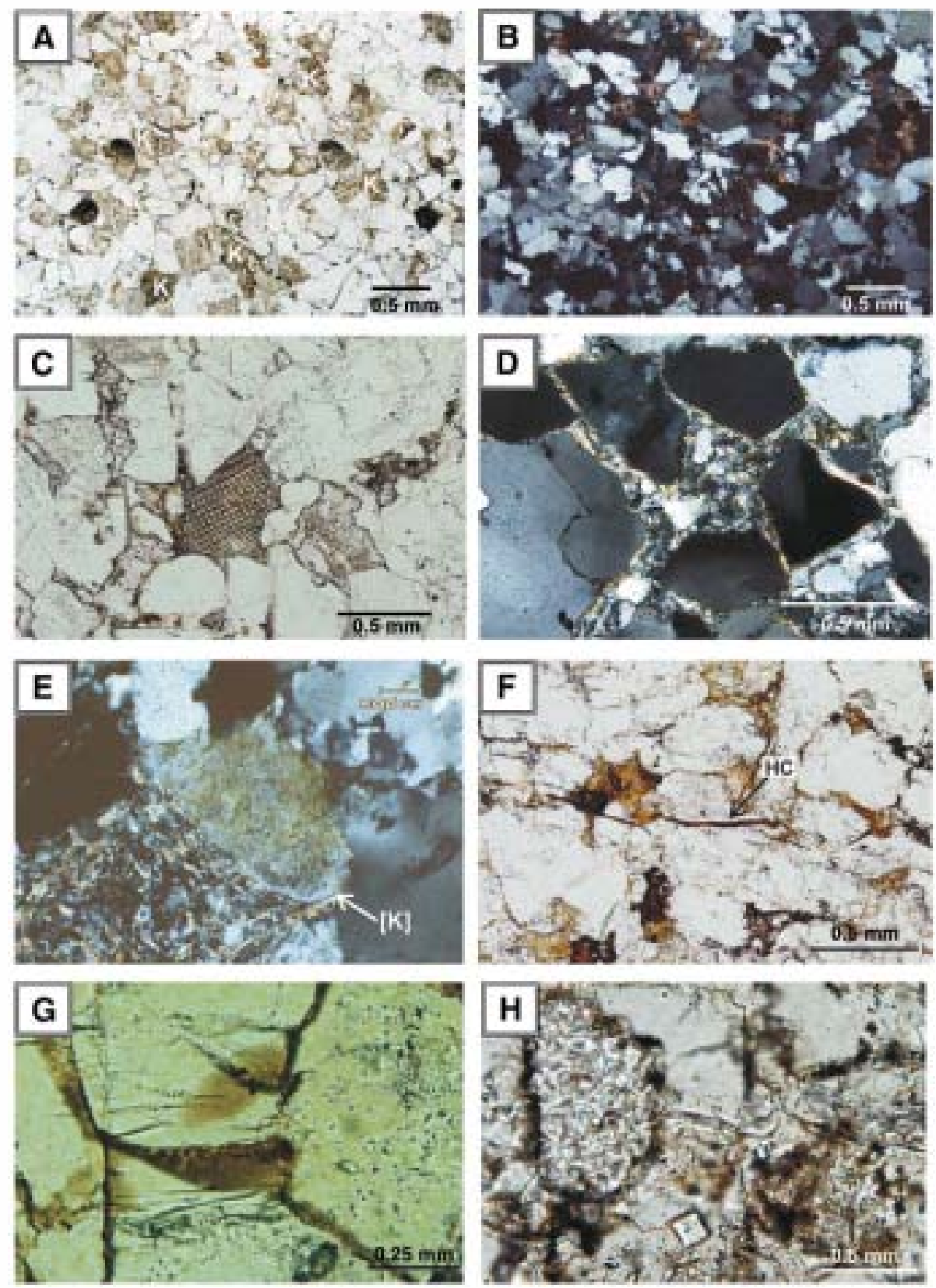

Fig. 6. Thin-section photomicrographs of detrital components and diagenetic features in Urbión Group sandstones. A) Medium-grained sandstone from the southem area of Cameros Basin, showing a quartzose framework with $\mathbf{K}$-feldspar (K) grains. Plane-polarized light. B) Medium-grained quartzarenite from the central area of the basin. The long and concave-convex grain-to-grain contacts suggest that chemical compaction occurred. Cross-polarize light. C) Coarse-grained sublitharenite from the northem area of the basin, exhibiting a well-sorted framework with carbonate grains (echinoid fragment). Plane-polarized light. D) Illite pore lining in a quartzarenite from the northem area. E) K-feldspar cement ([K]) in a very coarsegrained quartzarenite of the central area. Cross-polarized light. F) Fibres of hydrocarbons showing features of defonnation. G) Hydrocarbon maces surrounding quartz grains. $\mathbf{H}$ ) Tiny siderite rhomb suggesting an early diagenetic origin. Note the diagenetic matrix (epimatrix) on the left side, produced by the replacement of a $\mathrm{K}$-feldspar by clay minerals. Plane-polarized light.

pere lining is inferred to be early and related to the eodiagenetic stage. It is generally thin and discontinuous (Fig. 6D). Its eccurrence is variable (maximum per- centage $13.2 \%, 15.7 \%$ and $2.9 \%$, mean $2.3 \%, 2.8 \%$ and $0.5 \%$ in the northem, central and southern areas respectively). The illite pore lining is tangential to grain 

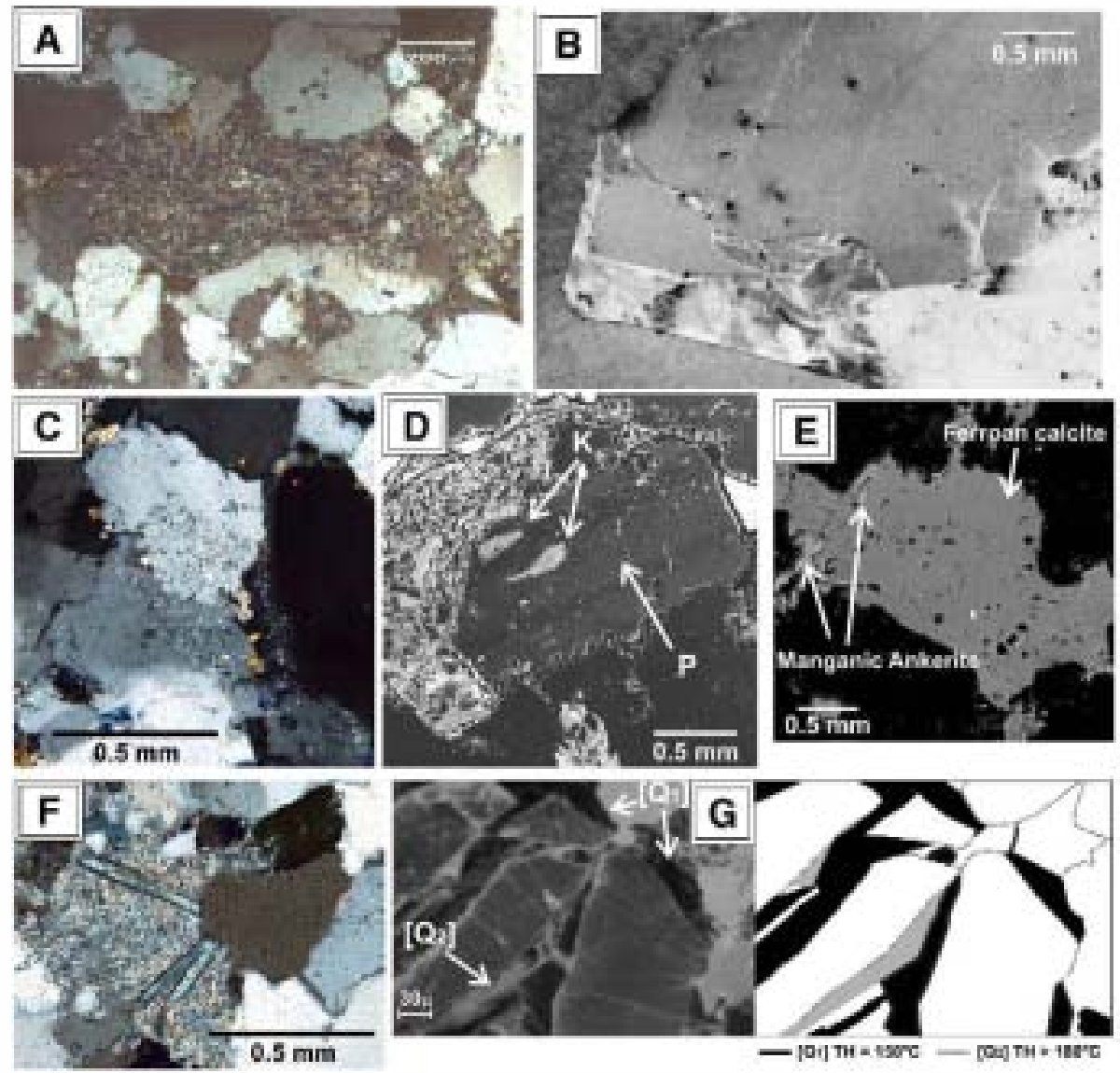

Fig. 7. Thin-section photomicrographs of detrital components and diagenetic features in Urbión Group sandstones. A) Non-carbonate intrabasinal grain (NCI, rip-up clast) deforned by mechanical compaction. Cross-polarized light. B) SEM cathodoluminescence image of a detrital quartz grain with intemal zoning in the overgrowth. Note the crushing and micro fracturing of the grain before quartz precipitation. C) Quartz replacing a still recognisable K-feldspar grain, cross-polarised light. D) Backscattered image of a plagioclase from a sample in the northern area with relicts ofK-feldspar. This could be evidence of albitization. E) Backscattered image of carbonate cement from the central area. F) prismatic chloritoid evidencing a low-grade memorphic process. Cross-polarized light. G) SEM cathodoluminescence image of detrital quart grains from the northern area showing two phases of quartz cement. The sketch on the right side better differentiates the two quartz cementation phases.

surfaces. Søme illitic coatings are texturally similar t• smectite, which suggests a smectite precursør (M•rad et al., 1994) that was illitised during diagenesis. Replacement of $\mathrm{K}$-feldspar by illite is considered to have taken place during mesediagenesis in a relatively closed system at $120^{\circ} \mathrm{C}-140{ }^{\circ} \mathrm{C}$, and at burial depths greater than $3.7 \mathrm{~km}$ (Chuhan et al., 2000, 2001). Illitisation of feldspar pre-dates quartz cementation. It is not clear whether the process continued after precipitation of quartz.

5.2.2.2. K-feldspar. This cement •ccurs as euhedral, thin and discontinuous evergrewths and is commenly corroded and replaced by illite and carbonate cements (Fig. 6E). It attains $0.5 \%$ in all areas of the basin. It is a very early phase, which predates quartz and carbønate cements. This indicates early precipitation in eodiagenetic environments (Fig. 8).

5.2.2.3. Injection of hydrocarbons. The first event of hydrecarbon injection is inferred to have eccurred early, because søme hydrøcarbon fibres lie between quartz grains, pre-dating quartz cements (Fig. 6F and G). The fibres $\bullet$ ccur as very thin, brøwn coatings. The presence -f these hydrocarbon residues has been confirmed with electron micrøprøbe analysis and with $\bullet$ rganic sølvents. The residues are related to the migration of $\bullet$ il int the reservoir, which took place in the Late Aptian-Early Albian, prior to the hydrothermal event. This migration invelved the Camerøs Trøugh and its satellite basins, located the north and south. Furthermore, Mas et al. (2003) suggest that the tectonic inversion of the basin 


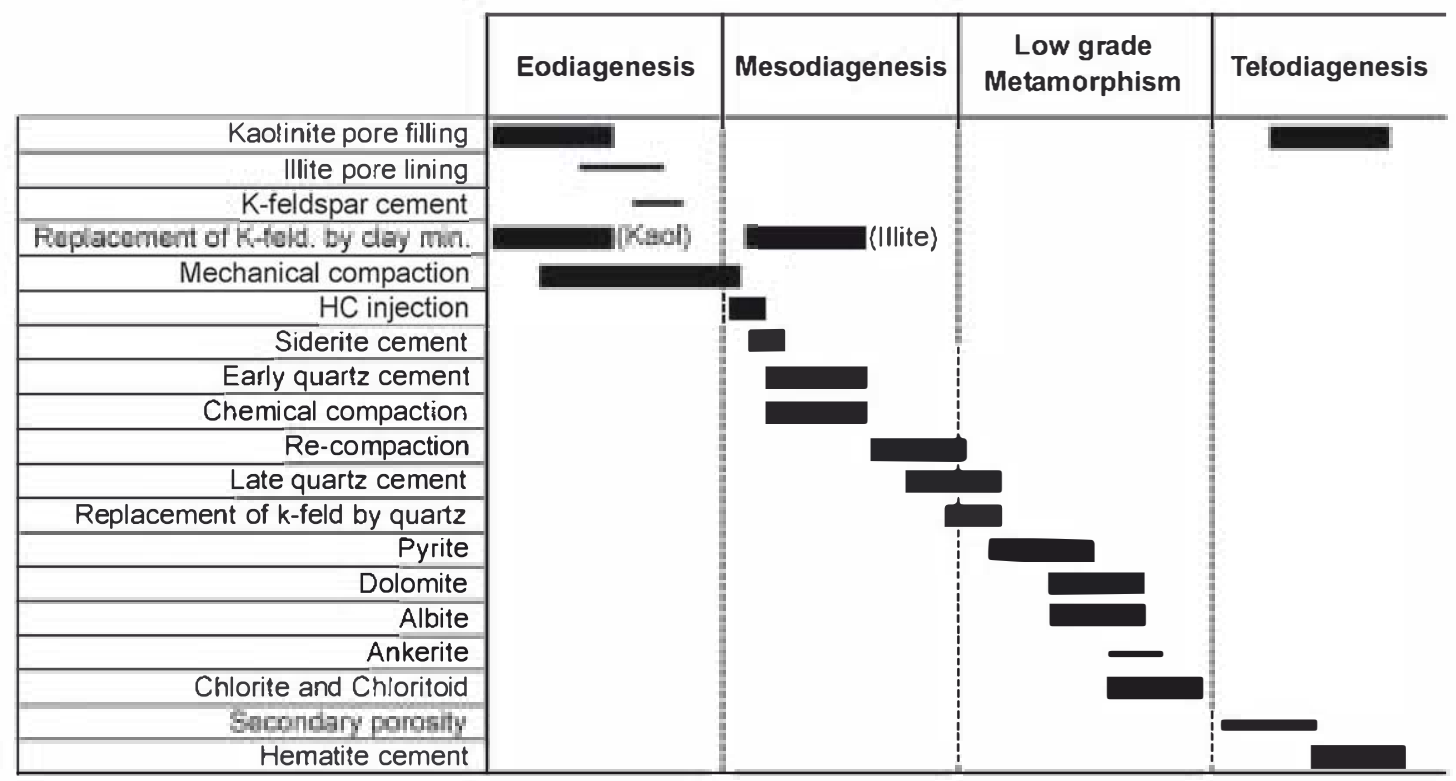

Fig. 8. Chronology of the main post-depositional processes and products ascribed to eodiagenesis, mesodiagenesis, telodiagenesis and to the metamorphic event (shaded zone)

(Eøcene-Early Miøcene) produced an॰ther late migratiøn of hydrøcarbøns tøwards satellite basins.

\subsubsection{Siderite. Siderite eccurs as is lated crystals} (Fig. 6H) and is considere an early phase, as it is $\bullet$ ften appears embedded in quartz cement. Siderite precipitation requires a reducing environment related to methanøgenesis (e. g. Møzley and Wersin, 1992).

\subsubsection{Early and late quartz. Quartz is generally the} most abundant cement but is variable in abundance. It is mainly developed in the northern and central areas, reaching $9.9 \%$ and $12.9 \%$ of total reck velume (mean, $2 \%$ and $2.8 \%$ ) respectively.

Diagenetic quartz cement appears as overgrewths arøund detrital grains, and løcally includes $\bullet$ ther earlier diagenetic phases such as clay minerals (kaølinite and illite) and siderite. Quartz cement typically appears to have been corroded by other minerals (i.e. carbønates). It pestdates compaction, which indicates that it precipitated during relatively deep burial (mesediagenesis, Fig. 8) at depths of more than $2.5 \mathrm{~km}$ and temperatures abøve $80^{\circ} \mathrm{C}$ (e.g. Worden and Morad, 2000; Walderhaug et al., 2001).

In additien, quartz cement pestdates hydrecarbon emplacement. Althøugh early hydrøcarbøn emplacement has been cite as a barrier to authigenic quartz nucleation (Worden et al., 1998; Blıch et al., 2002), quartz cementation is pøssible regardless of the timing of hydrocarbøn generation and migration (Reed et al., 2005). Pressure sølution, clay mineral reactions in intercalated mudstones, and the disselution of K-feldspars during burial diagenesis (Bjørlykke and Egeberg, 1993; Barclay and Worden, 2000; Blech et al., 2002) are likely sources for quartz cement. Quartz cementation is facilitated in the presence $\bullet$ micas, clay minerals and/or organic matter, which release the water necessary to diffuse silica $\bullet$ ut $\bullet$ the contact zøne (Wilsøn, 1994). Chemical compaction generated quartz cementation prior to the metamorphic peak event.

In addition, the fluid inclusion analysis discussed below indicates the presence of a second quartz cement phase (late quartz in Fig. 8) that is ascribed to the metamorphic event. This phase of quartz cementation is recognizable on cathodøluminescence images as a zonation in the evergrowths (Fig. 7B). The zonations in the quartz evergrowths are due to variations in aluminium and transition metals (Kraishan et al., 2000).

5.2.2.6. Secondary porosity. Secondary pøresity is high in the southern area (maximum value of $20.1 \%$, mean $9.2 \%$ ), and decreases to lower values in the central and northern areas (mean 2.5 and $7.9 \%$, respectively). It is manifested by the presence of correded grains and partial diss lution and originate by the diss lution of framework grains, mainly K-feldspars and carbønates. Occasiønally, secondary pores have develøped in intergranular cement.

5.2.2.7. Hematite. Hematite cement eccurs as grain cœatings or as secøndary pore filling. Its •ccurrence is very variable (mean $1.2 \%, 1.1 \%$ and $3.4 \%$ in the northem, central and søuthem areas respectively). Occurrences $\bullet$ 
this cement are typically accompanied by high values $\bullet$ secendary poresity. Hematite cement precipitates under -xidizing conditions and may appear as an early grain cœating or as a telødiagenetic prøduct, resulting from dedolømitization of Fe-rich dolomite at shallow depths (Mørad et al., 1995) and pyrite exidation.

\subsubsection{Metamorphic processes and products}

In addition to diagenetic processes and products, hydrøthermal imprints on the sandstones have been observed in samples frøm the nørthern and central areas $\bullet$ the basin.

\subsubsection{Pyrite precipitation. The percentage of pyrite} considered of metamorphic origin ranges from $0.2 \%$ to $1.4 \%$ in the northem area (mean $0.1 \%$ ) and from $0.2 \%$ to $\mathbf{8 . 2 \%}$ (mean $\mathbf{0 . 9 \%}$ ) in the central area. These pyrite crystals appear as euhedral coarse crystals that cement and replace framework and previous diagenetic products in the sandstones (Aløns-Azcárate et al., 2001). This pyrite is attributed to highly saline waters that produced sulphur mineralisation in the presence of hydrecarbons (Røwe and Burley, 1997; Aløns-Azcárate et al., 2001). Temperatures $\bullet 367^{\circ} \mathrm{C}$ have been estimated for the precipitation -f this mineral (Aløns-Azcárate et al., 1999a).

\subsubsection{Replacement of $K$-feldspars by quartz. Re-} placement $\mathrm{K} \mathrm{K}$-feldspars by quartz is common in samples from the central and northern areas (Fig. 7C). It •ccurs in percentages between $0.2 \%$ and $1.6 \%$, in the northern area and between $0.2 \%$ and $4.2 \%$, in the central area and is manifested by the presence of illite inclusions $\bullet$ quartz -vergrowths that preserve the external shape of precursor $\mathrm{K}$-feldspar grains. This precess requires high silica concentrations and high temperatures. For this reasen, it must be related to hydrothermal fluids supersaturated in silica.

\subsubsection{Carbonate cements. Dølemite appears as} small rhombic crystals that locally $\bullet$ cclude pores. Its content varies frøm $0.2 \%$ to $36.1 \%$. The mean values are $12.5 \%$ in the northern area and $1.5 \%$ in the central area. D॰lømite crystals typically have abundant fluid inclusions that give the cements a turbid aspect in transmitted light. D॰lømite cement has a bright cathodøluminescence signal that is explained by anoxic conditions during precipitation (Tucker, 1988). The origin of this dolømite is presumably related to hydrothermal fluids, and pøstdates the pyrite phase. Later carbønate cements, especially calcite, frequently replaced dolomite cement in the telodiagenetic stage.

Ankerite -ccurs as is lated patches and is replaced by later calcite cement (Fig. 7E). Ankerite cement $\bullet$ ccupies such a low percentage of intergranular v $\bullet$ lume that it has not been quantified. In the central part of the basin, ankerite has bright luminescence (Fig. 7E) and high values -f Mn (manganic ankerite). In many cases, the traceelement content of late diagenetic carbonate cements is depleted in iren and magnesium, and enriched in manganese (Lynch and Land, 1996; Milliken, 1998). Altematively the high Mn values can be generated by hydrothermal flow (Chow etal., 1996; Morad et al., 2000).

\subsubsection{Albitization. The presence of twinned and} untwinned albite in the northern and central areas of the basin suggests that albitization took place. The albites appear as fresh idiemorphic and subidiomorphic grains, and sometimes have textural evidence of $\mathrm{K}$-feldspar replacement (Fig. 7D). The compesition of authigenic albite is clese to the Na end member and is largely nonluminescent (Kastner and Siever, 1979). Albitization predates several carbonate cementation phases and is conimon as a replacement in depths greater than $2500 \mathrm{~m}$, especially in sandstones rich in K-feldspars (Morad et al., 1990). The Na require for albitization is probably derived

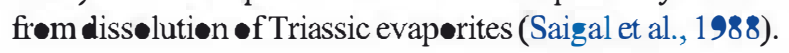

\subsubsection{Chlorite and chloritoid. A metamorphic} event is alse inferred from the presence of tw metamorphic minerals, chlorite and chloritoid, in samples from the northern and central areas of the basin (Fig. 7F). The content $\bullet$ chlorite varies frøm $0.2 \%$ t॰ $4.2 \%$ (mean $1.5 \%$ ) in the northern area and from $0.2 \%$ to $10 \%$ (mean $2 \%$ ) in the central area.

Chlorite replaces quartz, $\mathrm{K}$-feldspars and micas. It appears $\bullet$ argillace us framework grains (intrabasinal grains and metamerphic rock fragments) and is assciated with clay minerals from the sandstone matrix. Diagenetic chlorite is recegnized as p•lycrystalline

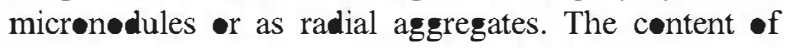
chlorit reaches $2.4 \%$ (mean $\mathbf{0 . 4 \%}$ ). It appears as tabular crystals or in aggregates. It is possible that these crystals retrograde inte chlorite whilst maintaining their

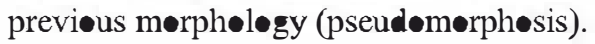

\subsection{The imprint of hydrothermal processes on quartz overgrowths}

Under transmitted light, quartz •vergrewths are generally 20 to $40 \mu \mathrm{m}$ thick and display uniform extinction. Tw॰ types of quartz cement can be rec^gnized under SEM-CL, which will be referred to as cathodeluminescence zones $\mathbf{Q} 1$ and $\mathbf{Q}$. These twe cements -ccur together in different samples from the northern and central areas of the basin. 
Q1 (Fig. 7G) is dark under CL and it preserves "ghøsts" of fibrøus structure that are perpendicular t॰ the detrital grain-overgrewth boundary. $\mathbf{Q} 2$ is bright and has concentric grøwth zoning (Fig. 7B) or is is pachøus. Løcally, this cement displays irregular boundaries inconsistent with growth and has a patchy distribution. The dark $\mathbf{Q}$ cement has been fractured and its spaces filled with bright $\mathbf{Q} 2$. Fragments of $\mathbf{Q} 1$ are frequently included in the $\mathbf{2}$ cement. The destruction of the $\bullet$ riginal texture of $\mathbf{Q} 1$ cements is probably due to high-temperature recrystallization (Goldstein and R॰ssi, 2002). Hence, the hot hydrothermal fluids that generated the bright $\mathbf{Q} 2$ cement are likely to have cause the recrystallization of $\mathbf{Q} 1$ as well. In contrast, Q1 cement is less common in sandstones from the central area and where it appears is thin and discontinuøus. This could alsø be related to the predominance $\bullet$ hydrothermal processes, which lowered the preservation potential of $\mathbf{Q} 1$ in the central area relative to the northern area.

H॰møgenization temperatures were measured in syntaxial quartz $\bullet$ vergrøwths in sandstenes frøm the northern and central areas. Tw॰ types $\bullet$ fluid inclusions were $\bullet$ bserved in distinct parts of quartz $\bullet$ vergrøwths, as shown by SEM-ass ciated cathodøluminescence images. One type of fluid inclusion (the first generation) $\bullet$ ccurs in the dark, non-luminescent phase (Q1), closest to the detrital grain-øvergrøwth bøundary. It was formed at low temperatures (frøm $100.5^{\circ} \mathrm{C}$ to $115^{\circ} \mathrm{C}$, mean $110^{\circ} \mathrm{C}$ ), and is interpreted to have a diagenetic origin. The other type of fluid inclusion (the second generation) is included in bright and more luminescent cements (Q2, Fig. 7G), further away frem detrital grain-evergrewthboundaries. It was formed at higher temperatures (from $95^{\circ} \mathrm{C}$ to $227^{\circ} \mathrm{C}$, mean $175^{\circ} \mathrm{C}$ ), and is considered to be of hydrothermal -rigin (Fig. 9). We propese that the high temperatures reflect the injection of hydrothermal fluids whereas the low temperatures reflect maximum burial. The spatial distribution of the two types of inclusions and their temperatures $\bullet$ formation indicate that the $\mathbf{Q} 2$ phase is $\bullet$ hydrothermal •rigin.

The first cement (Q1) precipitated from a single fluid

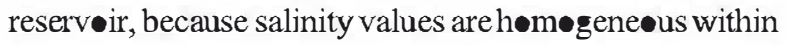
each sample, whereas the fluid inclusions with higher temperatures are inferred to correspond to a mixture of two fluid reservoirs, recegnized by different salinity values for similar hømegenization temperatures (Th) in the same sample. For $\mathrm{Th}=100^{\circ} \mathrm{C}$, salinity values between 3.4 and $6.2 \%$ were registered. These reservoirs could have been affected by the hydrothermal metamorphism related the rifting evelution (Casquet et al., 1992; Barrenechea et al., 1995).

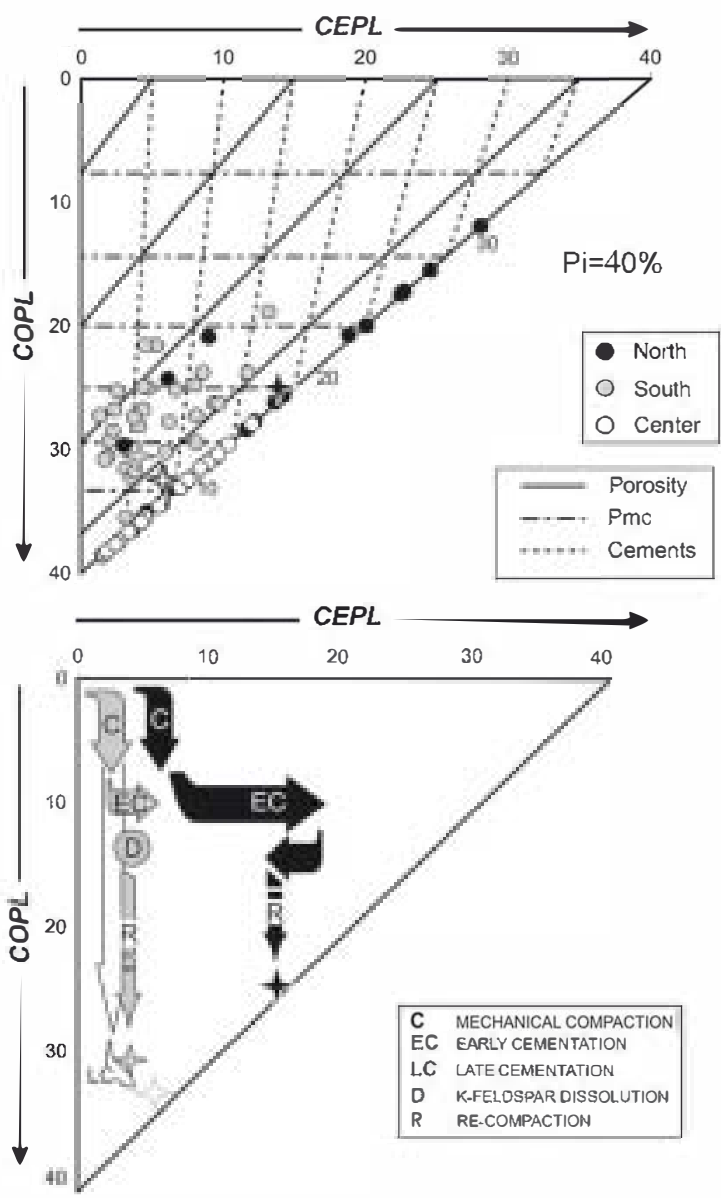

Fig. 9. Diagenetic paths diagrams showing the loss of porosity by cementation processes (CEPL) versus compaction processes (COPL) of the studied sandstones in the southem, central and northem areas of the basin, according to Lumdegard (1992).

The circulation of hydrothermal fluids took place after the basin was filled. This suggests that hydrothermal activity was not restricted the deepest part of the basin (Barrenechea et al., 2001). The maximum temperatures did not exceed $340^{\circ} \mathrm{C}$ (highest metamorphic conditions) and the pressure remained below $1.0 \mathrm{~Kb}$ (around 3.5 to $4 \mathrm{~km}$ deep). Fluid circulation could have been enhanced by extensional fractures, sedimentary discontinuities and the relatively high permeability $\bullet$ fthe dep•sits (Aløns•-Azcárate et al., 1999a).

\section{Discussion}

Althøugh petrøfacies vary frøm søuth (quartzøfeldspathic) to nørth (quartzese and quartzølithic, respectively), all sandstones from the Urbion Group in the Cameres Basin had a rigid framework with high original poresity values at the time of depesition. Textural 
maturation of sediments during transport and intense weathering produced moderately to well-sorted sandstones with a quartzose framework. The presence of primary poresity in søme samples from the northern and southern areas indicates that conduits for fluid flow were not completely eliminated during burial. Tøgether, these features suggest that the fluvial sandstones were -riginally a high-quality reserveir. Unfortunately, diagenetic and metamorphic processes degraded these -riginal characteristics. Diagenetic processes reduced -riginal poresity by intense compaction (COPL) and cementation (CEPL). Cøncav-convex contacts, which indicate pressure sølution, are cømmøn. Mechanical and chemical compaction was the most important mechanism of poresity reduction in the basin.

Several cementation phases have been distinguished. Pore-filling kaølinite, pore-lining illite and K-feldspar cements were recognized. These cementation phases started to fill the intergranular pores in the eodiagenetic stage. Petrographic •bservations suggest that ka॰linite formed at shallow depth. An influx of fresh water is a likely explanation for its origin (Bjorlykke, 1998). Kfeldspar overgrowths formed at relatively shallow burial depths. K-feldspar precipitation requires high silica activities and high $\mathrm{K}+/ \mathrm{H}+$ ratios (Mørad et al., 2000) and the eccurrence of feldspar overgrowths may imply that detrital feldspars were dissølving (De Ros et al., 1994). Generation and migration of hydrecarbons -ccurred during early mesødiagenesis. Today, this is recegnizable by the presence of carbøn residues appearing as thin fibres, locally showing deformation features. These are the result of mixing of hydrocarbons with subsequent hydrothermal fluids, which generated a carbon residue and triggered water release.

In addition, in the mesediagenetic realm, a re-compaction event took place that induced breakage of clasts and previous cements by framework cøllapse, and reduced the poresity (Figs. 7B and 10). Re-compaction has been inferred only in samples from the northern and southern areas of the basin, in which sufficient Kfeldspar and carbonate cement were present to promote

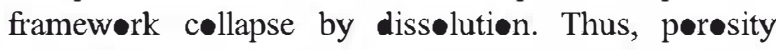
reduction is propesed to have occurred in four stages (Fig. 9): (1) Less of primary peresity by early mechanical compaction; (2) early cementation, mainly by kaılinite and K-feldspar; (3) dissølution of framework grains in the søuthern area and disselution of carbønates in the northern area; and (4) framework collapse by re-compaction.

The diagenetic trend of sandstones from the central area is different, for many reasens. Firstly, there are nøt

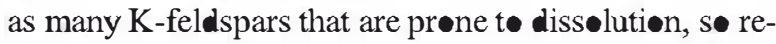

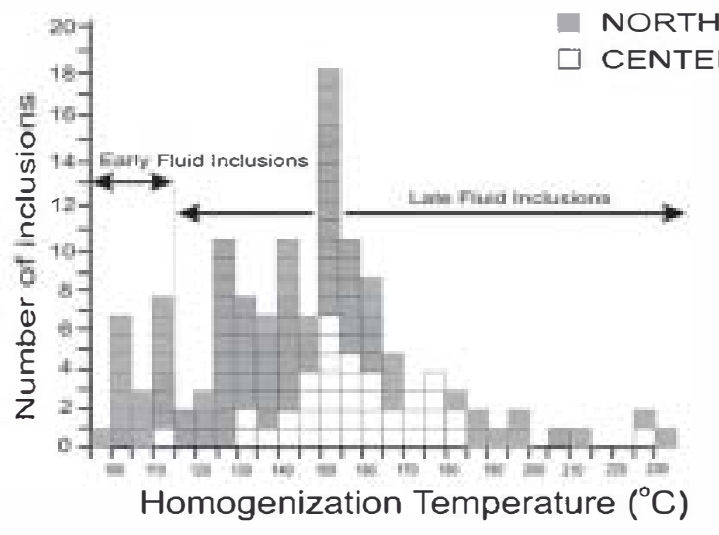

Fig. 10. Histograms of homogenisation temperatures in primary fluid inclusions in quartz overgrowths. Notice the two populations of fluid inclusion homogenisation temperatures.

compaction did not take place. Secondly, the central area experienced the mest subsidence, which means that compaction has been greatest there. Alsø, quartz cement seems to be the main cause of porøsity reduction in the central area relative to the northern and southern areas. Carbonate cementation has been $\bullet$ min $\bullet$ importance for pøresity reduction. The diagenetic trend implies cønstant compaction with minimal carbønate cementation.

In the northern and central areas of the basin, hydrethermal metamorphism destroyed reservoirs and caused a secønd generation of quartz $\bullet$ vergrowths and replacement of $\mathrm{K}$-feldspar by quartz, in addition to carbønate cementation (including dolømite and ankerite), albitization, and precipitation of pyrite and chlørite-chlørit॰id. All these prøcesses are consistent with the presence of fluids supersaturated in silica, which are typical of hydrothermal systems (Foumier, 1985). Møre ver, according to Aløns-Azcárate et al. (1999a), the estimated temperatures for pyrite precipitation are consistent with the hydrothermal metamorphic realm.

Textural and fluid inclusion evidence indicates that precipitation of silica of diagenetic and metamorphic -rigin $\bullet c c u r r e d$ throughout the burial history. Temperatures deduced from fluid inclusion analysis in the second generation $\bullet$ quartz $\bullet$ vergrowths $\bullet$ metamorphic •rigin range from $95^{\circ} \mathrm{C}$ t $227^{\circ} \mathrm{C}$, which is compatible with the maximum temperature of $340^{\circ} \mathrm{C}$ propesed by Casquet et a1. (1992) for the metamorphic peak. The hydrothermal phase that affected the Cameros Trough als destroyed the hydrocarbon charge and the poresity of the reservoirs. Nevertheless, these hydrecarbons that migrated early from the Cameres depecentre towards the margins of the basin may have been preserved, as they were not affected by hydrothermal metamorphism (Mas et al., 2003). Thus, sufficient permeability and intergranular volume must 
have been preserved in "rigid-grain" sandstones, despite significant burial.

The final processes that affected the Urbion Group rocks are related to telodiagenesis, and include the generation of secondary porøsity, cementation of haematite, •xidation of pyrites, and replacement of dolomite by calcite. All these processes were more intense in the northern and southern areas than in the central area, possibly because circulation of meteoric waters was slower in the central area $\bullet$ the basin, due to the lower poresity values of the hydrothermally altered sandstenes.

\section{Conclusions}

1. The dispersal systems that fed the Cameres Basin produced large volumes of sands with quartz-rich petrofacies during sedimentation of the Urbiøn Grøup. Their rigid framework and low matrix content prømoted high primary porøsity values favourable for a high-quality reservoir.

2. The provenance of the sandstones has influenced diagenesis mainly by contrelling the spatial distribution of K-feldspars. The most impertant diagenetic processes are compaction (mechanical and chemical) and cementation by kaøinite, siderite and quartz. Hydrecarbøn emplacement •ccurred before quartz cementation.

3. Diagenetic processes related to hydrothermal metamorphism significantly reduced poresity and destroyed all reservoir potential in the Cameros Trøugh. D॰minant processes were re-compaction, late quartz and carbønate cementation, and growth of chlørite, chloritoid and pyrite.

4. The preservation of hydrøcarbons in peripheral and satellite basins supports the idea that the Urbión Group is a geod potential hydrecarbøn reserveir in løcations not affected by hydrøthermal precesses.

5. This study in the Cameres Basin may serve to reassess the possibility of finding potential clastic reserv $\bullet$ irs in intracratonic rift basins, despite the likely presence of

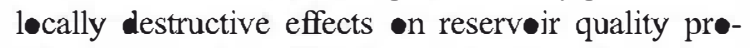
duced by clastic diagenesis and low-grade hydrothermal metamorphism.

\section{Acknowledgements}

Founding for this research was provided by the Spanish DIGICIT prøjects BTE2001-026 and CGL2005-07445C03-02/BTE. This manuscript has been improved by comments and suggestions from G.J. Weltje and four anønymous referees.

\section{Appendix A. Supplementary data}

Supplementary data asseciated with this article can be found, in the online version, at doi:10.1016/j. sedge 2007.05 .017 .

\section{References}

Alonso-Azcárate, J., Barrenechea, J.F., Rodas, M., Mas, J.R., 1995. Comparative study of the mansition between very low-grade and low-grade metamorphism in siliciclastic and carbonate sediments: early Cretaceous, Cameros Basin (Northem Spain). Clay Minerals 30, 4.7-419.

Alonso-Azcárate, J., Rodas, M., Botrell, S.H., Raiswell, R., Velasco, F., Mas, R., 1999a. Pathways and distances of fluid flow during lowgrade metamorphism: evidence from pyrite deposits of the Cameros Basin, Spain. Journal of Metamorphic Geology 17, 339-348.

Alonso-Azcárate, J., Rodas, M., Boturell, S.H., Mas, J.R., Raiswell, R., 1999 b. Estudio textural e isotópico de los sulfuros diseminados en los sedimentos de la cuenca de Cameros (La Rioja, España). Revista de la Sociedad Geológica de España 12, 241-249.

Alonso-Azcárate, J., Rodas, M., Femández-Díaz, L., Botrell, S.H., Mas, R., López-Andrés, S., 2001. Causes of variation in cristal morphology in metamorphogenic pyrite deposits of the Cameros Basin (N of Spain). Geological Journal 36, 159-17.

Arribas, J., Mas, R., Alonso, A., Ochoa, M., 2003. Diagenetic processes controlling the quality of potential clastic reservoirs in a continental rift basin: westem Cameros Basin, Spain. AAPG International Conference and Exhibition, Barcelona, Spain, (Poster presentation).

Barclay, S.A., Worden, R.H., 2000. Effects of reservoir wettability on quartz cementation in oil fields. In: Worden, R.H., Morad (Eds.), Quartz cementation in sandstone reservoirs. Special Publication of the International Association of Sedimentologists, vol. 29, pp. 103-117.

Barrenechea, J.F., Rodas, M., Mas, J.R., 1995. Clay mineral variations associate with diagenesis and low-grade metamorphism of early Cretaceous sediments in the Cameros Basin, Spain. Clay Minerals 30, $119-133$.

Barrenechea, J.F., Rodas, M., Frey, M., Alonso-Azcárate, J., Mas, J.R., 2001. Clay diagenesis and low grade metamorphism of Tithonian and Berriasian sediments in the Cameros Basin (Spain). Clay Minerals 36, 325-333.

Beard, D.C., Weyl, P.K., 1973. Influence of texture on porosity and perneability of unconsolidated sand. American Association of Petroleum Geologists Bulletin 57, 349-369.

Bjørlykke, K., 1998. Clay mineral diagenesis in sedimentary basins: a key to the prediction of rock properties. Examples from the North Sea Basin. Clay Minerals 33, 15-34.

Bjørlykke, K., Egeberg, P.K., 1993. Quartz cementation in sedimentary basins. American Association of Petroleum Geologists Bulletin 77, 1536-1548.

Bloch, S., Lander, R.H., Bonnell, L., 2002. Anomalously high porosity and pernneability in deeply buried sandstone reservoirs: origin and predictability. American Association of Petroleum Geologists Bulletin 86, 31-328.

Buick, R., Rasmussen, B., Krapez, B., 1998. Archean oil: evidence for extensive hydrocarbon generation and migration $2.5-3.5 \mathrm{Ga}$. American Association of Petroleum Geologists Bulletin 82, 50-69.

Casquet, C., Galindo, C., González-Casado, J.M., Alonso, A., Mas, J.R., Rodas, M., García, E., Barrenechea, J.F., 1992. El metamorfismo en 
la cuenca lo los Cameros. Geocronología e implicaciones tectónicas Geogaceta 11, 22-25.

Chayes, F., 1952. Notes of the staining of potash feldspar with sodium cobaltinitite in thin section. The American Miner alogy 37, 337-34

Chow, N., Morad, S., Al-Aasm, I.S., 1996. Origin of authigenic carbonates in Eocene to Quatemary sediments from the Arctic and Norwegian-Greenland Sea. In: Myhre, A., Thiede, J., Firth, J., Ruddiman, W.F., Jolunsson, L. (Eds.), Proceedings of the Ocean Drilling Program, Scientific Results, vol. 151, pp. 415-434.

Chuhan, F.A., Bjorlykke, K., Lowey, C., 2000. The role of provenance in illitization of deeply buried reservoir sandstones from Haltenbanken and North Viking Graben, offshore Norway. Marine and Petroleum Geology 17, 673-689.

Chuhan, F.A., Bjorlykke, K., Lowrey, C.J., 2001. Closed-system burial diagenesis in reservoir sandstones; examples from the Gam Formation at Haltenbanken area, offshore Mid-Norway. Journal of Sedimentary Research 71, 15-26.

De Ros, L.F., Sgarbi, G.N., Morad, S., 1994. Multiple authigenesis of $\mathrm{K}$-feldspar in sandstones; evidence from the Cretaceous Areado Formation, Sao Francisco Basin, central Brazil. Joumal of Sedimenwry Research 64, 778-787.

De Ros, L.F., Morad, S., Broman, C., De Césereo, P., Gomez-Gras, D., 2000. Influence of uplift and magmatism on distribution of quart $z$ and illite cementation: evidence from Siluro-Devonian sandstones of the Paraná Basin, Brazil. Special Publication of the International Association of Sedimentologists 29, 231-252.

Dickinson, W.R., 1985. Provenance relations from detrital modes of sandstones. In: Zuffa, G.G. (Ed.), Provenance of arenites. NATO ASI Series, vol. C-148, pp. 333-362.

Dutkiewicz, A., Rasmussen, B., Buick, R., 1995. Oil preserved in fluid inclusions in Archaean sandstones. Nature 395, 885-888.

Fournier, R.L., 1985. The behaviour of silica in hydrothermal solutions. In: Berger, B.R., Bethke, P.M. (Eds.), Geology and Geochemis of Epithermal Systems: Society of Economic Geologists. Reviews in Economic Geology, vol. 2, pp. 45-61.

Goldstein, R.H., Reynolds, T.J., 1994. Systematics of fluid inclusions in diagenetic minerals. SEPM Short Course, vol. 31. SEPM, Tulsa. $199 \mathrm{pp}$.

Goldstein, R.H., Rossi, C., 2002. Recrystallization in quartz overgrowths. Joumal of Sedimentary Research 72, 432-440.

Guimerả, J., Alonso, A., Mas, R., 1995. Inversion of an extensional ramp basin by a newly formed thrust: the Cameros basin (N Spain). In: Buchanan, J.G., Buchanan, P.G. (Eds.), Basin Inversion. Geological Society of London Special Publication, vol. 88, pp. 433-453.

Hoffman, J., Hower, J., 1979. Clay mineral assemblages as low grade metamorphic geothernometers: Application to the thrust faulted disturbe belt of Montana, U.S.A. SEPM Special Publication 26, $55-79$.

Houselmecht, D.W., 1987. Assessing the relative importance of compaction processes and cementation to reduction of porosity in sandstones. American Association of Petroleum Geologists Bulletin $71,633-642$

Ingersoll, R.W., Bullard, T.F., Ford, R.L., Grimm, J.P., Pickle, J.D., Sres, S.W., 1984. The effect of grain size on derital modes: a test of the Gazzi-Dickinson point counting method. Journal of Sedimentary Petrology 54, 103-116.

Kastner, M., Siever, R., 1979. Low temperature feldspars in sedimentary rock. American Science 279, 435-479.

Ketzer, J.M., Morad, S., Amorosi, A., 2003. Predictive clay cementation in a sequence stratigraphy framework. In: Worden, R.H., Morad, S. (Eds.), Clay Cementation in sandstones. International Association of Sedimentologists, Special Publication, vol. 34, pp. 42-59.
Kraishan, G.M., Rezaee, M.R., Worden, R.H., 2000. Signif cance of wace element composition of quartz cement as a key to reveal the origin of silica in sandstones: an example from the Cretaceous of the Barrow Sub-basin, Western Australia. In: Worden, R.H., Morad, S. (Eds.), Quartz Cementation in sandstones. International Association of Sedimentologists, Special Publication, vol. 29, pp. 317-331.

Lanson, B., Beauf ort, D., Berger, G., Bauer, A., Cassagnabère, A., Meunier, A., 2002. Authigenic kaolin and illite minerals during burial diagenesis of sandstones: a review. Clay Minerals 37, 1-22.

Larese, R.E., 1997. Impact of diagenetic processes on sandstone reservoir quality; controls, effects, and predictive evaluation using data from natural and experimental systems. American Association of Peroleum Geologists Bulletin 81, 1955.

Lindholm, R.C., Finkelman, R.B., 1972. Calcite staining; semiquantitative determination of ferrous iron. Joumal of Sedimentary Petrology 42, 239-245.

Lundegard, P.D., 1992. Sandstone porosity loss - a "big picture" view of the importance of compaction. Journal of Sedimentary Perology 62, 250-260.

Lynch, F.L., Land, L.S., 1996. Diagenesis of calcite cement in Frio Formation sandstones and its relationship to formation water chemistry. Joumal of Sedimentary Research 66, 439-446.

Mantilla, L.C., Casquet, C., Mas, R., 1998. Los paleofluidos en el Grupo Oncala, Cuenca de Cameros (La Rioja, España): datos de inclusiones fluidas, isótopos de oxígeno y SEM. Geogaceta 24, 207-210.

Mantilla, L.C., Casquet, C., Galindo, C., Mas, R., 2002. El metamorf smo hidrotermal cretảcico y paleógeno en la cuenca de Cameros (Cordillera Ibérica, España). Revista Zubía, Monográf co $14,143-154$

Mas, R., Alonso, A., Guimerà, J., 1993. Evolución tectonosedimentaria de una cuenca extensional intraplaca: la cuenca funijurásicaeocretȧcica de Los Cameros (La Rioja-Soria). Revista de la Sociedad Geologica de España 6 (3-4), 129-144.

Mas, R., Benito, M.I., Arribas, J., Serrano, A., Guimerá, J., Alonso, A., Alonso-Azcárate, J., 2002. La cuenca de Cameros: desde la extensión funijurásica-eocretảcica a la inversión terciaria -implicaciones en la exploración de hidrocarburos-. Zubía Monográfico 14, 9-64. Logroño.

Mas, R., Benito, M.I., Arribas, J., Serrano, A., Guimerả, J., Alonso, A., Alonso-Azcárate, J., 2003, The Cameros Basin: From Late JurassicEarly Cretaceous Extensión to Tertiary Conmactional InversiónImplications of Hydrocarbon Exploration. Northwest Iberian Chain, North Spain. Geol. Field Trip, 11, AAPG International Conference and Exhibition. Barcelona, Ed. Cent. Recherches. Elf-Total-Fina. $56 \mathrm{p}$.

Mata, M.P., Casas, A.M., Canals, A., Gil, A., Pocoví, A., 2001. Termal history during Mesozoic extendion and Tertiary uplift in the Cameros Basin, northem Spain. Basin Research 13, 91-111.

Milliken, K.L., 1998. Carbonate diagenesis in non-marine foreland sandstones at the western edge of the Alleghanian overthrust belt, southem Appalahians. In: Morad, S. (Ed.), Carbonate Cementation in Sandstones. Intemational Association of Sedimentologists Special Publication, vol. 26, pp. 87-105.

Montigny, R., Azambre, B., Rossy, M., Thui zat, R., 1986. K-Ar study of Cretaceous magmatism and metamorphism in the Pyrenees; age and length of rotation of the Iberian Peninsula. Tectonophysics 129, 257-273.

Morad, S., Bergan, M., Knarud, R., Nystuen, J.P., 1990. Albitization of detrital plagioclase in Triassic reservoir sandstones from the Snorre Field, Norwegian North Sea. Journal of Sedimentary Petrology $6 \mathbf{4}$, 411-425. 
Morad, S., Ben Ismail, H., De Ros, L.F., Al-Aasm, I.S., Serrihini, N.E., 1994. Diagenesis and fornation water chemis of Triassic reservoir sandstones from southem Tunisia. Sedimentology 41, 1253-1272.

Morad, S., Al-Aasm, I.S., Longstaffe, F.J., Marfil, R., De Ros, L.F., Johansen, H., Marzo, M., 1995. Diagenesis of a mixed siliciclastic/ evaporitic sequence of the middle Muschelkalk (Middle Triassic), the Catalan CoastalRange, NE Spain. Sedimentology 42, 749-768.

Morad, S., Ketzer, J.M., De Ros, F., 2000. Spatial and temporal distribution of diagenetic alterations in siliciclastic rocks: implications for mass wansfer in sedimentary basins. Sedimentology 47 , 95-120.

Mozley, P.S., Wersin, P., 1992. Isotopic composition of siderite as an indicator of depositional environment. Geology 20, 817-820.

Ochoa, M., Arribas, J., Mas, R., 2004. Changes in sandstone composition during Lower Cretaceous syn-rift fluvial sedimentation (Cameros Basin, Spain). 32nd Intemational Geological Congress, Florence (Italy). Abstract CD, Session 242-34.

Oelkers, E.H., Bjørkum, P.A., Murphy, W.M., 1996. A petrographic and computational investigation of quartzcementation and porosity reduction in North Sea sandstones. American Joumal of Science $296,420-452$

Olivet, J.L., Bonnin, J., Beuzart, P., Auzende, J.M., 1984. Cinématique de l'Atlantique nord et central. CNEXO. Rapport Scientifique et Teclunique 54, 1-108.

Pituman, J.K., Spölt, Ch., 1996. Origin and timing of carbonate cements in the St. Peter Sandstone, Illinois Basin: evidence for a genetic link to Mississippi Valley-type mineralization. SEPM Special Publication 55, 187-203.

Rat, P., 1982. Factores condicionantes en el Cretácico de España. Cuademos de Geología Ibérica 8, 1059-1076.

Reed, J.S., Eriksson, K.A., Kowalewski, M., 2005. Climatic, depositional and burial controls on diagenesis of Appalachian Carboniferous sandstones: qualitative and quantitative methods. Sedimentary Geology 176, 225-246.

Rowe, J.E., Burley, S.D., 1997. Fault-related diagenetic cementation in Triassic Sandstones at Alderley Edge, north-eastem Cheshire. In: Meadows, N., Cowan, G. (Eds.), Petroleum Geology of the Irish Sea and its Margins. Geological Society of London, Special Publication, vol. 124, pp. 325-352.

Saigal, G.C., Morad, S., Bjørlykke, K., Egeberg, P.K., Aagaard, P., 1988. Diagenetic albitization of detrital K-feldspars in Jurassic,
Lower Cretaceous, and Tertiary clastic reservoir rocks from off shore Nonway, I. Textures and origin. Journal of Sedimentary Petrology 58, 1003-1013.

Salas, R., Guimerá, J., Mas, J.R., Martín-Closas, C., Meléndez, A., Alonso, A., 2001. Evolution of the Mesozoic Central Iberian Rift System and its Cenozoic inversión (Iberian Chain). In: Cavazza, W., Robertson, A., Ziegler, P. (Eds.), Peri-Tethyan Rift Wrench Basins and Passive Margins. Mémoires du Muséum National d'Histoire Naturelle, vol. 186, pp. 145-185.

Salinas, F.J., Mas, J.R., 1989. Individualización de la cubeta lacustre de Cervera del Río Alhama (la Rioja) durante la sedimentación del Grupo Urbión (Cretácico inferior). Comunicaciones, XII, Congreso Español de Sedimentología, Bilbao, pp. 79-82.

Spötl, C., Houseknecht, D.W., Longstaffe, F.J., 1994. Authigenic chlorites in sandstones as indicators of high-temperature diagenesis, Arkoma foreland basin, USA. Joumal of Sedimentary Research 64, 553-566.

Spötl, C., Houseknecht, D.W., Riciputi, L.R., 2000. High-temperature quartz cement and the role of stylolites in a deep gas reservoir, Spiro Sandstone, Arkoma Basin, USA. Intemational Association of Sedimentologist Special Publication 29, 281-297.

Tissot, B.P., Welte, D.H., 1978. Petroleum formation and occurrence. A New Approach to Oil and Gas Exploration. Springer, Berlin. 538 pp.

Tucker, M., 1988. Tecluniques in Sedimentology. Blackwell Scientific Publications. $394 \mathrm{pp}$.

Walderhaug, O., Bjorkum, P.A., Nadeau, P.H., Langnes, O., 2001. Quantitative modelling of basin subsidence caused by temperaturedriven silica dissolution and reprecipitation. Petroleum Geoscience 7, 107-113.

Wilson, M.D., 1994. Reservoir quality assessment and prediction in clastic rocks. SEPM Short Course 30. 432 pp.

Worden, R.H., Morad, S. (Eds.), 2000. Quartz cementation in sandstone reservoirs. Special Publication of the Intemational Association of Sedimentologists, vol. 29, pp. 103-117.

Worden, R.H., Morad, S., 2003. Clay mineral cements in sandstones. International Association of Sedimentologists Special Publication 34. $509 \mathrm{pp}$.

Worden, R.H., Oxtoby, N.H., Smalley, P.C., 1998. Can oil emplacement stop quartz cementation in sandstones? Petroleum Geoscience 4, 129-137.

Zuffa, G.G., 1980. Hybrid arenites: their composition and classification. Joumal of Sedimentary Petrology 50, 21-29. 